Goncharov, A.A., Bazhenov, V. Yu., Dobrovolskiy, A.M., Protsenko, I.M., and Naiko, I.V.

Institute of Physics of the NAS of Ukraine, 46, Nauki Ave., Kyiv, 03028, Ukraine,

+380 44525 2329, gonchar@iop.kiev.ua

\title{
RECENT ADVANCES IN THE DEVELOPMENT OF EROSION SOURCES OF PLASMA
}

Introduction. Erosion sources of plasma provide a highly productive formation of ion-plasma streams by evaporating the electrode material and have been widely used in science and industry for synthesizing various coatings, modifying material surfaces, and for creating the sources of charged particles.

Problem Statement. At present, the main problem in creating high-quality coatings is their limited homogeneity due to the presence of the microdroplet phase in ion-vapor stream of erosion plasma sources.

Purpose. To create a new generation of erosion plasma sources, particularly, of vacuum arc-type ones that are free of microdroplets in order to efficiently synthesize high-quality coatings with predetermined functional properties.

Materials and Methods. For creating sources of pure metal plasma, an original idea based on the use of axially symmetric plasma-optical system for introducing additional energy into a flow of dense multi-component metal plasma due to efficient self-sustained generation of fast electrons has been proposed. Such energetic electrons are able to effect the plasma flow passing through the system and, particularly, to evaporate and to eliminate microdroplets that essentially limit the use of erosion dense plasma sources for technological developments.

Results. Conceptual design of combined source containing vacuum arc plasma source and axially symmetric cylindrical electrostatic plasma-optical lens in a single device has been created. The designed hardware does not have analogs worldwide.

Conclusions. The research has opened up wide prospects for practical application of the proposed idea for removal undesired micro-impurities while keeping the mass transfer in metal plasma flow formed by vacuum arc source. Combination of plasma lens with vacuum arc ion source enables controlling low energy plasma flux towards the substrate (i.e., film deposition) or towards emission grid (i.e., ion beam generation).

Keywords: erosion plasma source, dense plasma, plasma-optical system, and microdroplets.

Plasma erosion sources are a wide range of ionplasma flux sources, including vacuum-arc and laser-generated ones, widely used in science and industry for the synthesis of various coatings and the creation of charged particle sources. The plasma erosion sources are used in industrial methods for modifying surfaces of structural and decorative materials. At the same time, their use in creating high quality coatings, especially those with a

(C) GONCHAROV, A.A., BAZHENOV, V. Yu., DOBROVOLSKIY, A.M., PROTSENKO, I.M., and NAIKO, I.V., 2019 highly uniformity at the nanoscale, and coatings for optical applications is limited by the presence of the micro-droplet phase in the flux. The problem of the presence of micro-inclusions in the ionvapor flux of erosive plasma sources (vacuum-arc ones) and its purification from them, has been discussed in many researches [1-6] that describe the basic schemes of filters and ways of preventing the presence of droplet phase in the working flux. However, the existing filtration systems are mainly based on the separation (removal) of the droplet phase substance from the flux. This ap- 


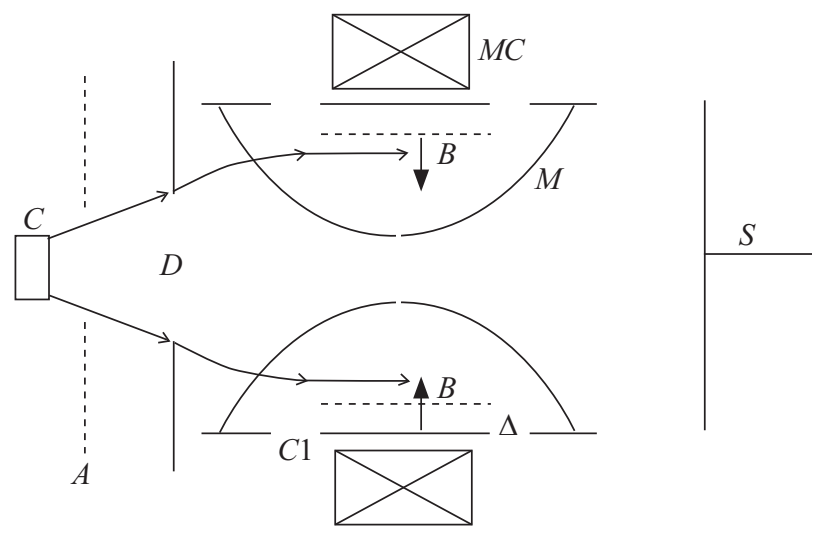

Fig. 1. Scheme of the system for removing micro-droplets from plasma flux: $C$ - cathode; $A$ - anode; $D$ - diaphragm; $M C$ - magnetic coil; $M$ - magnetic field lines; $\Delta$ - spatial layer in which a strong electric field is formed; $C 1$ cylindrical electrode that generates an electron beam under the action of secondary ion-electron emission; $S$ - substrate for coating

proach causes a significant reduction in the process productivity.

The researchers of the Institute of Physics of the NAS of Ukraine (IP NASU) have suggested an idea of filtration system that does not require removing the droplet phase substance from the flux, but, on the contrary, enhances the productivity of ion-plasma treatment. The key feature of this development is a beam of fast electrons bringing additional energy to the flux of metal plasma passing through the system, for the effective evaporation and destruction of the microdroplets. Such high-energy electrons can be formed selfconsistently while passing through the plasma flux, as a result of secondary ion-electron emission from the cylindrical electrodes of the plasma-optical system.

The plasma-optical systems (plasma lenses) based on the fundamental plasmodynamic idea of magnetic isolation of electrons and the equipotentialisation of the power lines of the isolating magnetic field have proved a success in terms of focusing and controlling high-energy ion beams and ion fluxes [7]. Such systems in the fast electron generation mode can be promising for their use as modified plasma-optical filters capable of removing the micro-droplets from erosive plasma sources.

Theoretical assumptions and experimental demonstrations conducted at the IP of NASU have shown that the suggested idea for removing the micro-droplets is innovative and effective in developing a new plasma system for filtering the micro-droplets (or reducing them to the nanoscale) from dense metal plasma flux generated by such erosion plasma sources as a vacuum arc and a laser plasma source. At the current stage of the research, vacuum-arc plasma sources have been used in the experiments. The first results that testify to a high prospective viability and practical potential of this idea have been presented in [8-12].

Below, there are the results of studying different modes of operation of a vacuum-arc plasma source with a plasma-optical filter, which have led to the conceptual design of optimized assembly "vacuum-arc plasma source - modified cylindrical plasma lens with non-equipotential electrodes".

Having considered all possible energy channels of interaction of multicomponent plasma particles with liquid metal particles having a typical diameter of $1-10 \mu \mathrm{m}$, as described in [1], it was suggested that at the expense of its own resources the plasma flux from vacuum arc could not evaporate the droplets while transporting to the substrate for applying coatings and synthesizing thin films. Without going into details of various proposals for the introduction of additional energy into low-temperature dense plasma flux, below, there is outlined the essence of the proposed original and physically transparent approach. A schematic illustration of the cutting-edge plasma-optical system using an electron beam to effectively remove the micro-droplets in metall plasma flux propagating in the system is shown in Fig. 1. Highly ionized multicomponent plasma with micro-droplets is formed by a vacuum arc source with cathode $C$ and anode $A$. Usually, the flux passes through several screens before leaving the source aperture. Typically, such systems have screens and apertures, which partially remove the droplets. Immediately after the aperture, the flux enters the plas- 
ma optic device. Applying a negative potential to the central electrode $C 1$ leads to the formation of a layer with a strong electric field mainly directed towards the radius. A significantly smaller electric field penetrates into the metal plasma flux. Such conditions lead to the formation of a spatial layer with a thickness $\Delta<<\rho_{\mathrm{e}} \equiv$ $\equiv \mathrm{e} E_{r} / m_{e} \omega_{H e}^{2}$ and a large radial electric field $E_{r}$, near the electrode. It should be noted that the system is placed in a magnetic field where the inequalities $\rho_{H e}<<D<<\rho_{H i}$. shall be met. Here, $\rho_{H e}$ and $\rho_{H i}$ are the Larmor radii of electrons and ions, and $D$ is the filter diameter. In this system, the electrons are magnetized while the ions are not magnetized. Under typical conditions, an electronegative potential of $-1-3 \mathrm{kV}$ is applied to the central cylindrical electrodes of the system. As a result, the secondary ion-electron emission forms an electron beam with velocity $V_{b}=$ $=\left(2 \mathrm{e} U / m_{e}\right)^{1 / 2}$ and current density $j_{b}=\gamma j_{i}$, where $\gamma$ is the secondary ion-electron emission factor. This electron beam is formed in a self-consistent manner in a thin layer $\Delta<<\rho_{e}==V_{b} / \omega_{H e}$, while plasma flux is passing through it, due to some plasma ions that accelerate in this layer in the direction of the central electrode. According to the estimates, for typical parameters of a plasma flux formed by a vacuum-arc source, the ion energy in the flux is $\varepsilon_{i} \approx 20-60 \mathrm{eV}$ and the electron plasma temperature $T_{e}$ and their density $n_{0}$ are $T_{e} \approx 2-4 \mathrm{eV}, n_{0}=10^{11}-10^{12} \mathrm{~cm}^{-3}$, respectively. For the cylindrical filter electrodes having a diameter of $70 \mathrm{~mm}$ in a magnetic field of $200-$ $400 \mathrm{Oe}$, the mentioned inequalities are met in a wide range of experimental conditions.

Thus, the electron beam formed on the inner surface of the central cylindrical electrode of the plasma-optical filter adds to the propagating plasma flux a significant portion of the energy that exceeds all energy accumulated in the plasma ions and electrons. Under the action of elastic and inelastic collisions with neutral atoms and charged plasma particles in the crossed electric and magnetic fields, this beam is directed to the axis of the system. In this case, the beam electrons can col-

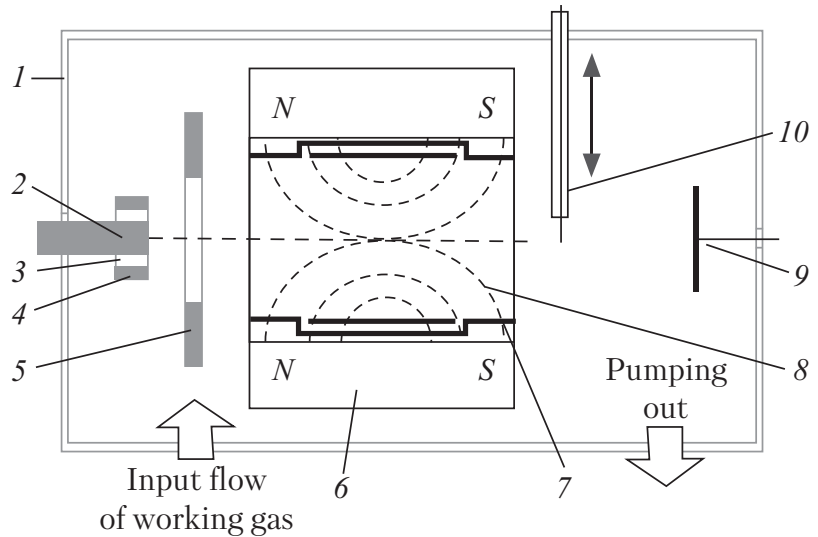

Fig. 2. Scheme of the experimental device: 1 - vacuum chamber; 2 - cathode of the vacuum-arc source; 3 - insulating ring; 4 - electromechanical ignition electrode; 5 anode of the vacuum-arc source; 6 - system of permanent magnets and filter magnetic conductor; 7 - filter electrodes; 8 - magnetic field lines that close pairwise the terminal electrodes of the filter; 9 - substrate; 10 - radial probe. The source is isolated from the chamber

lide with metal droplets and thereby lead to their evaporation and destruction.

The device for experimental verification of the effectiveness and promising viability of the new idea of purification of multicomponent metal plasma flux from the micro-droplets is shown in Fig. 2. A Bulat-type vacuum-arc system of continuous action has been used. The arc discharge current is $60-80 \mathrm{~A}$, the discharge voltage is $22 \mathrm{~V}$, at a magnetic field strength in the filter $B=0 \mathrm{Gs}$, and $30 \mathrm{~V}$, at $B=360 \mathrm{Gs}$. The diameter of the copper cathode is $20 \mathrm{~mm}$. The stainless steel substrate has a surface area of $1 \mathrm{~cm}^{2}$ and is placed under a negative potential of $-200 \mathrm{~V}$. The distance from the cathode to the substrate is $250 \mathrm{~mm}$. The time of application of the coating is $3 \mathrm{~min}$.

In the experimental device, a three-electrode plasma-optical filter is used as micro-droplet filter, with the terminal electrodes connected to each other and grounded, and a negative potential of $-1 \div 1.5 \mathrm{kV}$ applied to the central electrode. A $360 \mathrm{GHz}$ induction magnetic field is generated by permanent magnets. The filter length is $15 \mathrm{~cm}$, the inner diameter of the electrodes is $68 \mathrm{~mm}$, the width of the central electrode is $69 \mathrm{~mm}$, that of the terminal ones is $25 \mathrm{~mm}$. 


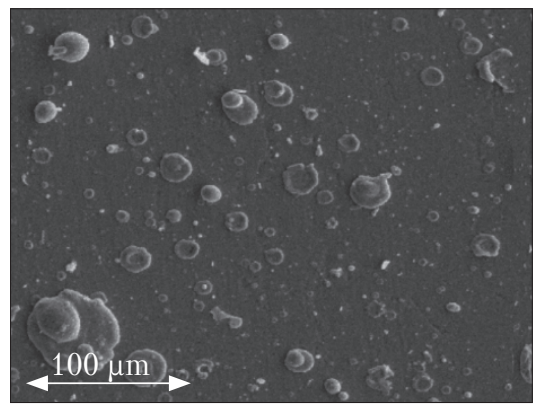

$a$

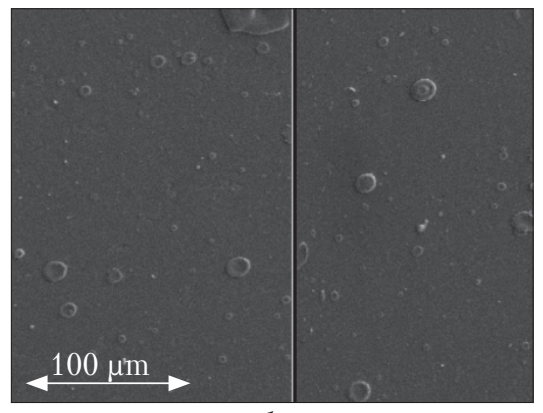

$b$

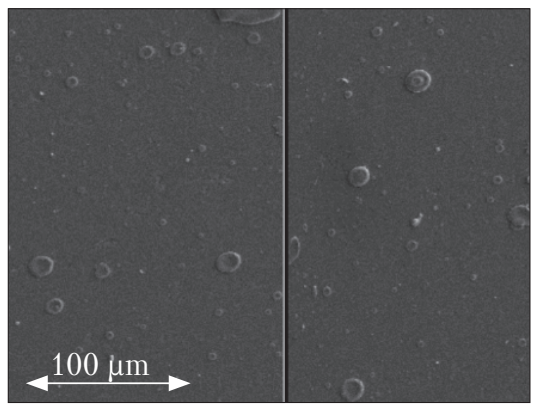

C

Fig. 3. Effect of destruction of copper micro-droplets on the sample surface (the apparent area is $250 \times 330 \mu \mathrm{m})(\mathrm{SEM})$ : $a$ - filter is off; $b$ - filter operates in the mode $U=-1000 \mathrm{~V}, B=0 ; c-$ filter operates in the mode $U=-1000 \mathrm{~V}, B=360 \mathrm{Gs}$

The samples with the deposited copper film are studied using a scanning electron microscope (SEM). The images for different filter modes are shown in Fig. 3. A significant reduction in the number of micro-droplets, both in and without the magnetic field (i.e. in the hollow cathode mode) has been reported. Also, it should be noted that there is a decrease in the diameter of large droplets that have passed through the plasma-optical filter.

The experiments with the first option of the plasma-optical filter have shown some disadvantages of its design. In particular, the study of the magnetic field effect on its performance is questionable. Also, the design of the electrode system does not enable flexibly varying the distribution of potential applied to the filter electrodes. All this has led to improvements of the filter design and the transition to the pulse-periodic mode of operation for systematic experimental studies.

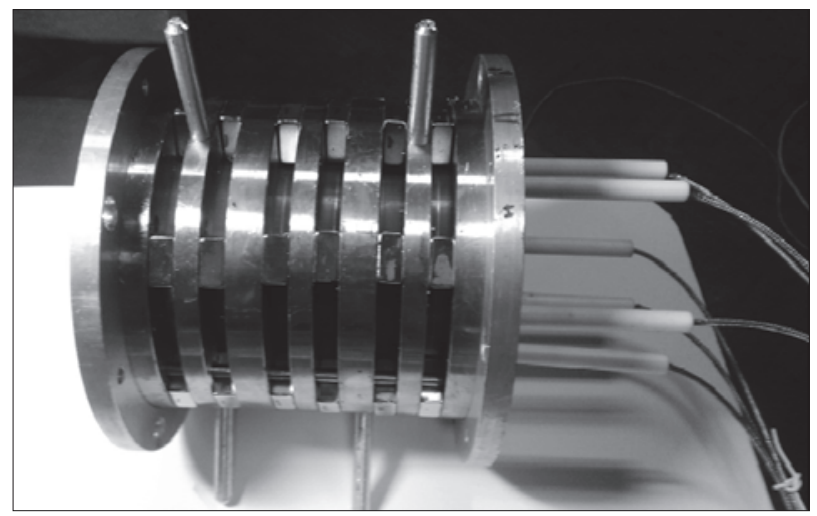

Fig. 4. Advanced plasma-optical filter
Using the existing software and the experience gained in the design of plasma-optical systems has allowed us to create a device containing on its external side a magnetic circuit with permanent magnets and a system for supply of potential to the electrodes of the electrode system (Fig. 4). The magnetic circuit is made of soft magnetic iron and Nd-Fe-B permanent magnets. The average magnetic field induction on the surface of a single parallelepiped magnet is $0.3 \mathrm{~T}$. The system has six spacings for the installation of individual permanent magnets having a thickness of up to $10 \mathrm{~mm}$ and a cross section of up to $20 \times 20 \mathrm{~mm}$. The inserts made of soft magnetic iron enable creating a continuous, uniform field in a large volume.

The filter electrode system is made of nonmagnetic materials. The electrodes, their leads, and the couplings are made of stainless non-magnetic steel. The insulation inserts are made of organic glass and fluoroplast. The device diagram (Fig. 5) shows the arrangement of the shaped insulating inserts that should eliminate the risks of short circuit between the electrodes at a high potential, which are grounded by means of the deposition of metal plasma from the cathode material on the channel walls. The low-energy plasma transport channel is formed by six pairs of electrodes and a dielectric between them. The electrodes have different widths and separate leads to each pair. They are placed symmetrically relative to the median plane of the lens. Such a large number of electrodes enables to flexibly select the shape of 


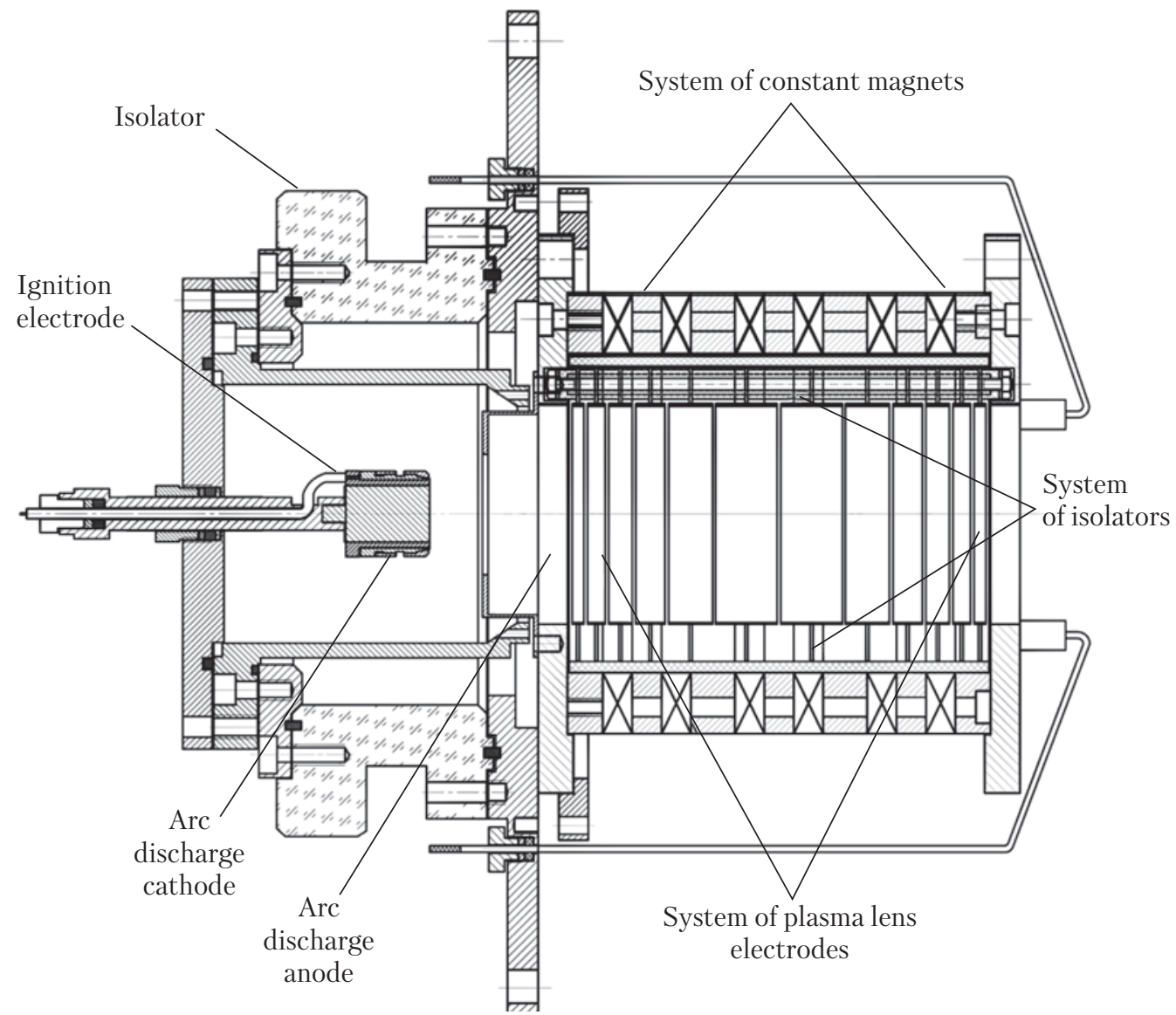

Fig. 5. Scheme of the integrated assembly "vacuum-arc plasma source - advanced plasma-optical filter". The inner diameter of the filter electrodes is $80 \mathrm{~mm}$

the potential distribution along the transport channel wall. The two middle electrode pairs are located within the area of a homogeneous magnetic field. The other pairs are placed within the gradient area, which increases the flexibility of the system as a whole.

The studies have shown that the most promising in terms of designing a virtually attractive technological device is the combined assembly "plasma source - plasma lens" that is an axiallysymmetric system consisting of an erosive source of vacuum-arc plasma and plasma-optical lens on permanent magnets, which enables generating crossed electric and magnetic fields that significantly affect the parameters of the propagating ion-plasma flux.
Also, the operation mode of the vacuum-arc plasma source has been modified, namely, the transition from continuous mode to the pulse-periodic one with a separate electro-physical ignition electrode has been done. The electrophysical parameters of the source are as follows: discharge current is $100-300 \mathrm{~A}$; pulse duration is $100-300 \mu$ s; pulse repetition period is $1-5 \mathrm{~s}$; residual pressure in the vacuum chamber is $1.5 \times 10^{-6}$ Tor; argon as working gas can be added up to a pressure of $1 \times 10^{-4} \mathrm{Tor}$; the cathode is made of copper (Ø6 mm) or titanium $(\varnothing 18 \mathrm{~mm})$. It should be noted that a cathode block of a commonly known MEVVA (metal, vapor, vacuum arc) type source of heavy metal ions is used in this case. The main parameters of the plasma-optical system are as follows: 


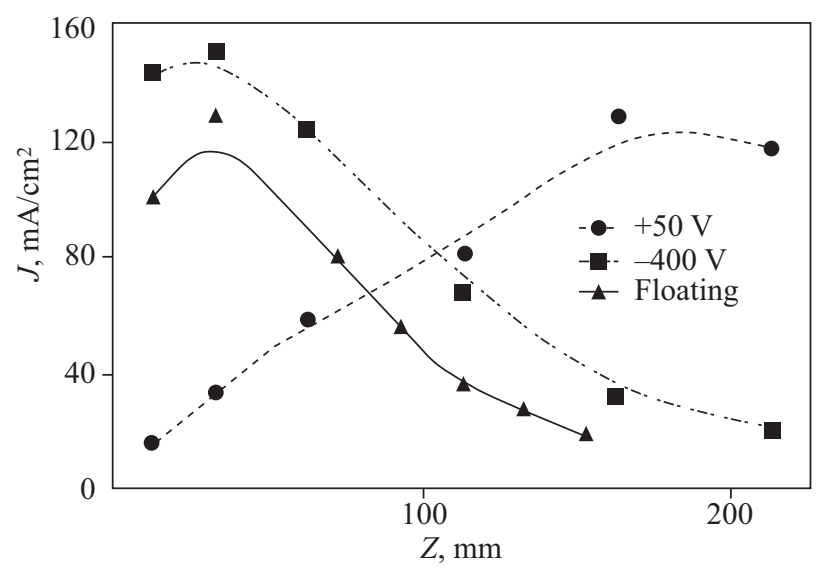

Fig. 6. Dependence of the current density of copper ions on the collector $J$ on its distance $Z$ from the output plane of the plasma-optical filter (discharge current is $100 \mathrm{~A}$, residual pressure is $1,5 \times 10^{-6}$ Tor, magnetic induction is $0.03 \mathrm{~T}$ )

a magnetic field with an induction of $\mathrm{B}=300 \mathrm{Gs}$ on the axis is generated by a system of permanent magnets; the negative potential at the central filter electrode varies up to $-3 \mathrm{kV}$; the terminal electrodes are grounded; the inner diameter of the filter electrodes is $80 \mathrm{~mm}$; its length is $14 \mathrm{~cm}$. The plasma flux that has passed through the filter has been studied using a partitioned collector consisting of 4 independent ring-shaped collectors, with the closest to the cathode terminal filter electrode acting as anode of the vacuum-arc source.

The results of plasmodynamic studies of the propagation of dense low-temperature ion-plasma flux in the developed system are shown in Fig. 6. They are averaged data of measurements of 6 plasma pulses, with the reference point of the $z$-axis corresponding to the reference plane of the lens. Although, in empty space, the plasma propagates with a considerable divergence, the obtained experimental results have shown that, within a certain range of gas pressure and potential applied to the central electrode, the overwhelming majority of the plasma flux passes the plasma-optical filter through. Moreover, under the mentioned experimental conditions, this system focuses the plasma flux, which is especially pronounced in the case of floating potential at the central electrode and, in our opinion, is caused by the formation of a self- consistent distribution of the focusing electric potential in the plasma flux. In this case, an additional potential difference of about $10 \mathrm{~V}$ is observed at the central electrode. It is rather sufficient for focusing a low-energy ion-plasma flux with an energy of $20-30 \mathrm{eV}$.

Also, one can observe focusing the plasma flux at the lens output when a negative potential is applied to the central electrode of the lens (supply voltage is $-500 \mathrm{~V}$, actual potential of the central electrode is about $-400 \mathrm{~V}$ ). This can be explained by the generation of fast electrons due to the secondary emission when the ions fall on the inner surface of the central electrode of the lens. These electrons, along with the slow plasma electrons, can accumulate on the axis and ensure focusing the flux ions due to the polarization effect.

In the pure plasma-optical mode, when the supply voltage of the central electrode is $+500 \mathrm{~V}$ (the actual potential at the central electrode is about $+50 \mathrm{~V}$ only), the plasma-optical focusing effect is weaker as compared with the other cases under review. This may be explained by a complicated configuration of the system due to the fact that the central electrode becomes the second vacuum-arc discharge anode.

In order to test the performance of the advanced plasma-optical filter, copper films have been deposited in the case of fully disconnected filter and in the case of a filter without a magnetic field. In the latter case, the filter electrode system forms the conditions for non-self-maintained or self-maintained discharge of the hollow-cathode type, depending on pressure in the chamber. In such a discharge, the electrons can have an energy of the level of difference of potentials applied to the discharge gap and, while colliding with the microdroplets, can destroy them.

The surface of the deposited layers has been studied using an optical microscope. Under the microscope, the sample surfaces have different appearances for different operating modes of the plasma-optical filter (Fig. 7). It can be seen that the number of droplets is significantly less in both cases, provided the filter is used. The maximum 


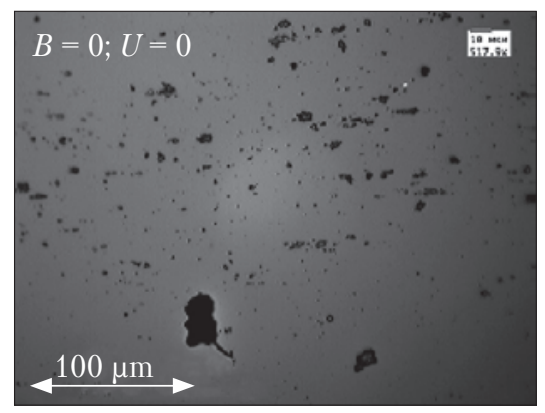

$a$

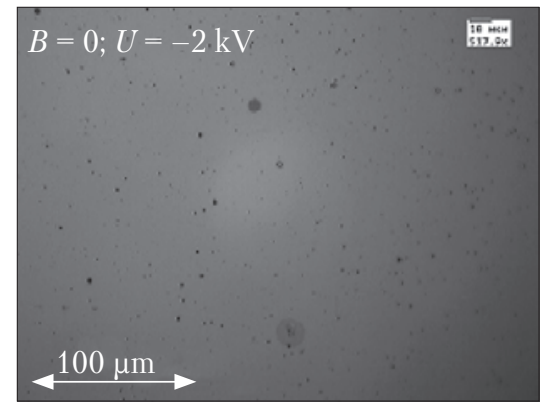

$b$

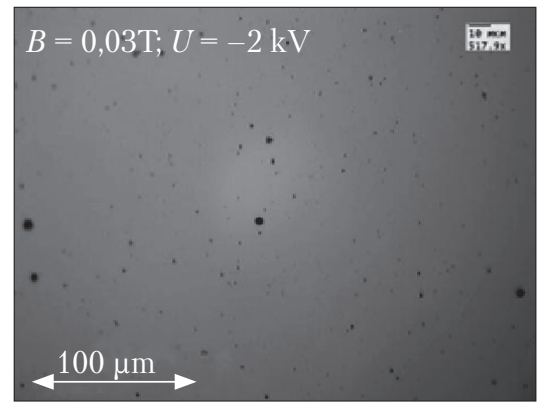

C

Fig. 7. Sample surface in different operating modes of the advanced plasma-optical filter (obtained with the use of an optical microscope): $a$ - filter is off; $b$ - filter operates in the mode $U=-2000 \mathrm{~V}, B=0 ; c$ - filter operates in the mode $U=-2000 \mathrm{~V}$,

$$
B=300 \mathrm{Gs}
$$

size of the droplets reaching the sample surface decreases as well. More efficient destruction of the droplets can be achieved by the further optimization of the filter parameters.

To check the performance of the filtration of plasma flux of high-melting-point metal ions in the designed system, the material of the cathode is replaced by titanium. For studying the titanium droplets on the sample surface, 3 types of substrates are used: conventional microscope slide, organic glass, and quartz glass. As a result of the visual examination of the sample surfaces treated under the same conditions the largest number of micro-droplets is detected on the surface of the quartz glass substrate. On the other surfaces, in addition to a smaller number of droplets, there are found the traces of micro-droplets that although reach the surface, but cannot have stayed on it. The most likely reason for the retention of droplets on the surface of quartz glass is its low thermal expansion coefficient. Due to this, even under a considerable temperature stress (cooling of the titanium droplet from the molten state to the normal conditions), the droplets remain on the surface. Proceeding from the above, in the future, only quartz glass substrates have been used for the research.

To compare the results for the different research conditions (filter off / on) the same parameters of the vacuum-arc source are used: the discharge current is $120 \mathrm{~A}$, the pulse duration is $1 \mathrm{~ms}$, the frequency of repetition is $1 \mathrm{~Hz}$, the pulse count is about 9000 (2.5-hour continuous operation), and the working gas (argon) pressure is $5 \times 10^{-4}$ Tor. When using the plasma-optical filter to purify the plasma flux from the micro-droplets, the hollow-cathode discharge current amounts to about 3.5 $\mathrm{A}$, and the voltage at the discharge cathode is about $-1.8 \mathrm{kV}$.

The initial observations have shown a relatively small number of titanium droplets as com-
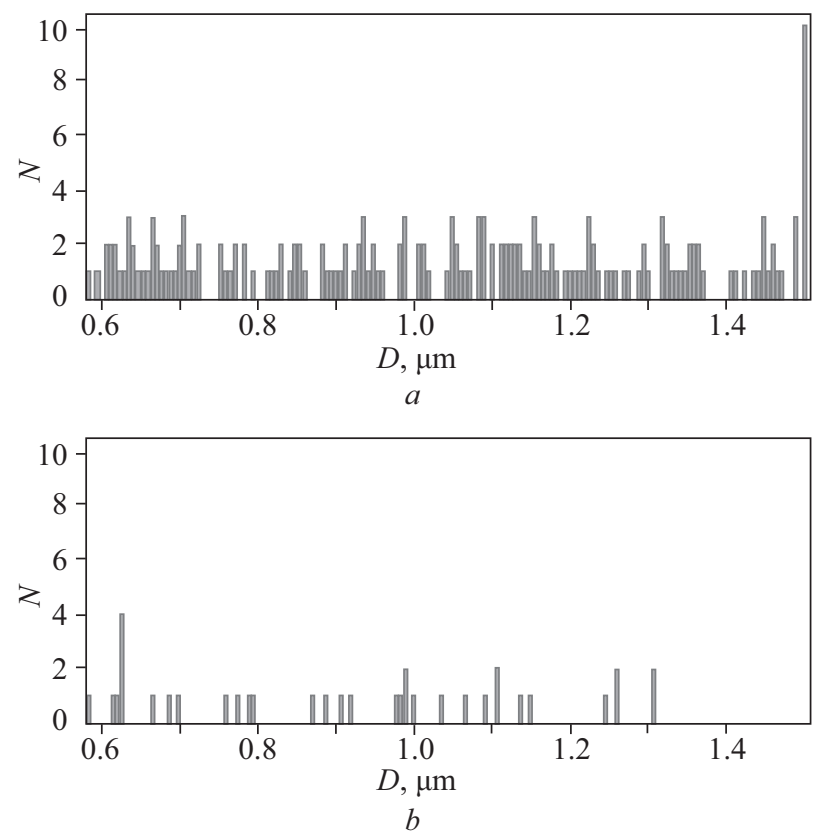

Fig. 8. Histogram of the size distribution of titanium microdroplets in the system "vacuum-arc plasma source-advanced plasma-optical filter": $a$ - filter is off; $b$ - filter operates in the mode $U=-1800 \mathrm{~V}, B=0$. The droplet size is calculated using the titanium reflective index $(R=0.5)$ 


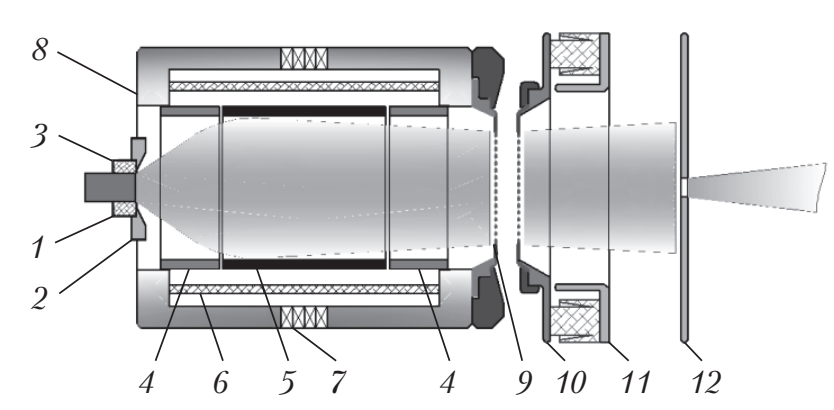

Fig. 9. Scheme of the modified combined MEVVA assembly and the plasma lens for improving the parameters of a vacuum-arc source of metal ions: 1 - cathode; 2 - ignition electrode; 3 - insulator; 4 - terminal electrodes; 5 - central electrode; 6 - insulator; 7 - magnetic system; 8 - magnetic circuit; 9-emission grid; 10 - suppressor; 11 - accelerating electrode; 12 - output aperture

pared with experiments with copper), even when the filter is off. The most likely, it is explained by a higher melting point of titanium as compared with copper. Due to this, for the same energy input into the arc discharge, at the copper cathode, there are visually detected several simultaneously existing stains versus one stain on the titanium cathode. Thus, the most efficient procedure for counting the droplets under a microscope required a much larger field of view, and, accordingly, a smaller magnification, as compared with the copper experiment. Obviously, this impairs the resolution, making small droplets invisible when using a conventional through illumination scheme. Therefore, it is necessary to use another counting method that would enable the detection of droplets that are lesser than the microscope resolution.

The main principle of the method for obtaining a surface image is to record the light reflection from the micro-droplets against a black background. The optical microscope is precisely focused by obtaining a minimum size of diffraction-limited images of small droplets. Using a $\times 10$ magnification (0.2 aperture lens) and a Canon 350D digital camera with a sensor size of $15 \times 22.5 \mathrm{~mm}$ has enabled simultaneous recording of the droplets in a sufficiently large field of view $(1.5 \times 2.25 \mathrm{~mm})$ and thus improving the quality of the statistical analysis. In this case, the resolution is about $1.5 \mu \mathrm{m}$ in the image plane.

The brightness of light reflected from the surface of droplets that are larger than the resolution does not depend on the size of the droplet $B=B_{0} R$, where $B_{0}$ is the brightness of the source, $R$ is the reflective index of titanium. For the droplets that are lesser that resolution, the apparent brightness decreases according to $B \approx B_{0} R\left(\mathrm{~d} / \mathrm{D}_{\mathrm{RES}}\right)^{2}$, where $d$ is the diameter of the droplet, and $\mathrm{D}_{\mathrm{RES}}$ is the system resolution. Thus, analyzing the sample image on a black background enables to count the droplets larger than $\mathrm{D}_{\mathrm{RFS}}$ and to obtain the size distribution for the smaller droplets.

The procedure for digital camera image processing is as follows:

1) converting a $R A W$ file to a 16 -bit TIFF (grayscale) with a gamma of 0.5 (UFRAW freeware) to obtain diameter distribution histograms;

2) selecting one pixel for each maximum intensity (ImageJ freeware);

3) building a histogram (accumulation window width is 256 , i.e. 256 values from the full range of 65536 .

The obtained results (Fig. 8) have undoubtedly shown a decrease in the number of micro-droplets when the filter is on. In this case, all large droplets (over 1.5 microns) are completely removed. There remains a small number of medium droplets (0.5-1.5 microns) that are likely the residues of the large ones that have not evaporated in the filter based on the hollow cathode discharge.

In addition to its application for filtering the micro-droplets in plasma flux, the cylindrical plasma lens type plasma-optical system has good prospects for being used in order to increase the efficiency of other plasma-optical systems, in particular, those designed to form beams of multicharge heavy metal ions. The scheme of using the plasma optic lens as element of a vacuum-arc ion source is shown in Fig. 9. The initial experiments on measuring the charge composition of copper ions that have passed through such a system with the simultaneous application of a magnetic field 
and an electronegative potential to the central electrode have shown a significant increase in the current of copper ions with charges from $1+$ to $4+$, namely, the emission current increases approximately from $0.25 \mathrm{~A}$ to $0.5 \mathrm{~A}$, in particular, the current of $\mathrm{Cu}^{3+}$ varies from $0.45 \mathrm{~mA}$ to $1.8 \mathrm{~mA}$, whereas that of $\mathrm{Cu}^{1+}$ ranges from $0.05 \mathrm{~mA}$ to $0.75 \mathrm{~mA}$. These values have testified to the focusing of the low-energy plasma flux in the direction of the emission grid and confirmed the ability of the fast electrons in the lens to control the average ion charge in the resulting multicharge ion beam. It should be noted that an increase in the current of ions with higher charges resulting from the use of such a system makes it attractive for practical applications as an input element of linear accelerators of heavy metal ions and in other modern ion-beam technologies for modifying the surface properties of materials.

Hence, as a result of the series of theoretical and experimental studies, a new axial-symmetric plasma-optic system for removing micro-droplets from a dense low-temperature multicomponent plasma flux generated by an erosive vacuum-arc plasma source has been created and tested. The achieved level of understanding of the physical processes arising in the system with fast electrons has allowed us to create an experimental model of a commercial prototype of the advanced erosion source of metal plasma, where a vacuum-arc source and a plasma-optical filter are combined in one device. This combined optimized assembly, having been adapted to the specific technological conditions, will be completely ready for practical applications in the synthesis of functional coatings with significantly improved properties. Another innovative promising result of the research cycle is the understanding that such an assembly in the mode of modified vacuum-arc source of multi- charge metal plasma ions gives an opportunity to create a new generation of widely known MEVVA (metal, vapor, vacuum arc) ion sources that have been successfully used in linear accelerators of heavy ions and in the process of modifying the surface properties of materials. However, this research requires further creative efforts to optimize and improve the system and can be an interesting example of innovative developments aiming at support of the sustainable development of the national economy.

The research has been done within the framework of the R\&D Instrument-Making Program of the NAS of Ukraine, project P13/16-18 and partly under the Advanced Studies in Plasma Physics, Controlled Fusion and Plasma Technologies Target Comprehensive Program, project Pl-18.

\section{REFERENCES}

1. Anders, A. (1997). Growth and decay of macroparticles: A feasible approach to clean vacuum arc plasmas. J. Appl. Phys., 82(8), 3679-3688. https://doi.org/10.1063/1.365731.

2. Boxman, R. L., Goldsmith, S. (1992). Macroparticle contamination in cathodic arc coatings: generation, transport and control. Surf. and Coat. Techn., 51(1), 39-50. https://doi.org/10.1016/0257-8972(92)90369-L.

3. Anders, S., Anders, A., Yu, K. M., Yao, X. Y., Brown, I. G. (1993). On the macroparticle flux from vacuum arc cathode spots. IEEE Trans. on Plasma Sci., 21(5), 440-446. https://doi.org/10.1109/27.249623.

4. Anders, A., Slack, J. (2012, September). Phase transitions in vacuum arcs in the context of liquid metal arc sources. Proceedings of the $25^{\text {th }}$ ISDEIV. Tomsk, Russia, P. 305-308.

5. Aksenov, I. I., Aksyonov, D. S., Vasilyev, V. V., Luchaninov, A. A., Reshetnyak, E. N., Strel'nitskij, V. E. (2009). TwoCathode Filtered Vacuum-Arc Plasma Source. IEEE Trans. on Plasma Sci., 37(8), 1511-1516. https://doi.org/10.1109/ TPS.2009.2018820.

6. Aksyonov, I. I. (2005). Vakuumnaya duga v erozionnyh istochnikah plazmy. Kharkov. 216 p. [in Russian].

7. Goncharov, A. (2013). Invited Review Article: The Electrostatic Plasma Lens. Rev. Sci. Instrum., 84(2), 021101. https://doi.org./10.1063/1.4789314.

8. Goncharov, A. A., Maslov, V. I., Fisk, A. (2012, May). Novel Plasma-Optical Device for the Elimination of Droplets in Cathodic Arc Plasma Coating. Society of Vacuum Coaters. 55 ${ }^{\text {th }}$ Annual Technical Conference Proceedings, Santa Clara, CA. P. $441-444$. 
9. U.S. patent application \# 2014/0034484A1 (6 February 2014). Fisk A., Maslov V., Goncharov A. Device for the Elimination of Microdroplets from a Cathodic Arc Plasma Source.

10. Goncharov, A. A. (2016). Recent development of plasma optical systems (invited). Review of Scientific Instruments, 87, 02B901. https://doi.org/10.1063/1.4931718.

11. Goncharov, A., Tsiolko, V., Dobrovol'skii, A., Bazhenov, V., Litovko, I. (2017). New generation plasmadynamical systems with fast electrons. Visnyk Kyivskogo Natsionalnogo Universytetu im. T. Shevchenka, Radiofizyka ta elektronika, 25(1), $13-22$.

12. Goncharov, A. A., Dobrovolsky, A. M., Bazhenov, V. Yu., Litovko, I. V., Naiko, I. V., Naiko, L. V., Kostin, E. G., Protsenko, I. M. (2018). Last results of novel plasmaoptical devices investigation. Problems of Atomic Science and Technology, 116(4), 36-39.

Received 04.12.18

Revised 28.02.19

Accepted 01.03.19

\section{О.А. Гончаров, В.Ю. Баженов, А.М. Добровольський, I.M. Проценко, I.В. Найко \\ Інститут фізики НАН України, просп. Науки, 46, Київ, 03028, Україна, +380 44525 2329, gonchar@iop.kiev.ua}

\section{НОВІТНІ ДОСЯГНЕННЯ В РОЗРОБЦІ ЕРОЗІЙНИХ ДЖЕРЕЛ ПЛАЗМИ}

Вступ. Ерозійні джерела плазми забезпечують високопродуктивне формування іонно-плазмових потоків шляхом випарювання матеріалу електродів та мають широке застосування у науці й промисловості для синтезу різноманітних покриттів, модифікації поверхні матеріалів та створення джерел заряджених частинок.

Проблематика. На сьогодні, проблемою у створенні високоякісних покриттів є їх обмежена однорідність, що зумовлено присутністю мікрокрапельної фази в іонно-паровому потоці ерозійних джерел плазми.

Мета. Створення нового покоління ерозійних плазмових джерел, зокрема, вакуумно-дугових, вільних від мікрокрапель, для ефективного синтезу високоякісних покриттів с заданими функціональними властивостями.

Матеріали й методи. Для створення джерел чистої металевої плазми було запропоновано та реалізовано оригінальну ідею використання аксіально-симетричної плазмооптичної системи для введення додаткової енергії у потік щільної багатокомпонентної металевої плазми за рахунок ефективного самоузгодженого утворення швидких електронів. Такі енергетичні електрони здатні ефективно впливати на плазмовий потік, що проходить крізь систему, випаровуючи та руйнуючи мікрокраплі, які суттєво обмежують використання ерозійних джерел щільної плазми для технологічних розробок.

Результати. Розроблено концептуальний проект комбінованого джерела, яке містить у одному пристрої вакуумно-дугове плазмове джерело та аксіально-симетричну циліндричну електростатичну плазмооптичну лінзу. Запропонована розробка є оригінальною та не має аналогів у світі.

Висновки. Наведені результати дослідження відкривають широку перспективність практичного застосування запропонованої ідеї для усунення небажаних мікровключень зі збереженням переносу маси у потоці металевої плазми, що формується вакуумно-дуговим джерелом. Поєднання плазмової лінзи з вакуумно-дуговим джерелом іонів відкриває нові можливості керування низькоенергетичним плазмовим потоком, що розповсюджується у напрямку до підкладки (при нанесенні плівок) або емісійної сітки (при генерації іонного пучка).

Ключові слова: ерозійне джерело плазми, щільна плазма, плазмооптична система, мікрокраплі. 


\author{
А.А. Гончаров, В.Ю. Баженов, А.Н. Добровольский, \\ И.М. Проченко, И.В. Найко \\ Институт физики НАН Украины, \\ просп. Науки, 46, Киев, 03028, Украина, \\ +380 44525 2329, gonchar@iop.kiev.ua

\section{НОВЕЙШИЕ ДОСТИЖЕНИЯ В РАЗРАБОТКЕ ЭРОЗИОННЫХ ИСТОЧНИКОВ ПЛАЗМЫ}

Введение. Эрозионные источники плазмы обеспечивают высокопроизводительное формирование ионноплазменных потоков путем испарения материала электродов и широко используются в науке и промышленности для синтеза различных покрытий, модификации поверхности материалов и создания источников заряженных частиц.

Проблематика. В настоящее время проблемой в создании высококачественных покрытий является их ограниченная однородность, что обусловлено присутствием микрокапельной фазы в ионно-паровом потоке эрозионных источников плазмы.

Цель. Создание нового поколения эрозионных источников плазмы, в частности, вакуумно-дуговых, свободных от микрокапель для эффективного синтеза высококачественных покрытий с заданными функциональными свойствами.

Материалы и методы. Для создания источников чистой металлической плазмы была предложена и реализована оригинальная идея использования аксиально-симметричной плазмооптической системы для введения дополнительной энергии в поток плотной многокомпонентной металлической плазмы за счет самосогласованного создания быстрых электронов. Такие энергетические электроны способны эффективно влиять на плазменный поток, проходящий через систему, в частности, испарять и разрушать микрокапли, существенно ограничивающие использование эрозионных источников для технологических разработок.

Результаты. Разработан концептуальный проект комбинированного источника, содержащего в одном устройстве вакуумно-дуговой источник плазмы и аксиально-симметричную цилиндрическую электростатическую плазмооптическую линзу. Предложенная разработка является оригинальной и не имеет аналогов в мире.

Выводы. Приведенные результаты исследования дают широкие перспективы практического применения предложенной идеи для устранения нежелательных микровключений при сохранении массопереноса в потоке металлической плазмы, формируемой вакуумно-дуговым источником. Объединение плазменной линзы и вакуумно-дугового пламенного источника открывает новые возможности для управления низкоэнергетическим плазменным потоком, распространяющимся по направлению к подложке (при нанесении пленок) или эмиссионной сетке (при генерации ионного пучка).

Ключевые слова: эрозионный источник плазмы, плотная плазма, плазмооптическая система, микрокапли. 